\title{
Índice de desvantagem vocal no canto clássico (IDCC) em cantores eruditos****
}

\author{
Classical singing handicap index (CSHI) in erudite singers
}

\author{
Maria Emília Barros de Ávila* \\ Gisele Oliveira** \\ Mara Behlau***
}

*Fonoaudióloga. Especialização em Voz pelo Centro de Estudos da Voz (CEV). Fonoaudióloga da Prefeitura Municipal de São Sebastião. Endereço para correspondência: R. João Batista Fernandes, 166 - Casa 4 - São Sebastião SP - CEP 11600-000

(maemiba@uol.com.br).

**Fonoaudióloga. Doutora em Distúrbios da Comunicação Humana pela Universidade Federal de São Paulo (Unifesp). Professora do CEV.

***Fonoaudióloga. Doutora em Distúrbios da Comunicação Humana pela Unifesp. Diretora do CEV.

****Trabalho Realizado no CEV

Artigo Original de Pesquisa

Artigo Submetido a Avaliação por Pares

Conflito de Interesse: não

Recebido em 21.12.2009. Revisado em 27.08.2010. Aceito para Publicação em 01.09.2010.

\begin{abstract}
Background: self-assessment of the impact of vocal deviation in the quality of life of erudite singers. Aim: to verify whether the presence of vocal complaints in erudite singers produces quality of life handicap in the use of singing voice and whether this handicap is related to gender, age, vocal classification or time of singing. Method: fifty-nine professional erudite choir singers answered the questionnaire including general questions such as identification, vocal classification, gender, time of study and dedication to classical singing. The choir singers were categorized into two groups, according to the presence of vocal complaints. They all answered the protocol Classical Singing Handicap Index (CSHI), which analyzes the impact of abnormal voice on singing voice in three subscales: Disability, Handicap and Impairment. Results: subscales Impairment (6.39) and Disability (5.39) presented higher scores than subscale Handicap (3.34) for all singers. Moreover, there was statistically significant correlation between presence of vocal complaint and higher score of CSHI ( $p>0.001$ to all subscales). In the group with complaints, women had higher score in subscale Disability than men. In the group without complaints, older subjects and those who had sung longer presented lower CSHI scores. Conclusion: singers with vocal complaints and/or symptoms had higher handicap index in singing, expressed in subscales Impairment and Disability, without relationship with vocal classification.
\end{abstract}

Key Words: Voice; Voice Quality; Quality of Life; Music.

\section{Resumo}

Tema: auto-avaliação da alteração vocal na qualidade de vida de cantores eruditos. Objetivo: verificar se a presença de queixa vocal em cantores eruditos produz desvantagem na qualidade de vida no que diz respeito ao uso da voz cantada e se tal desvantagem pode estar relacionada ao sexo, à idade, à classificação vocal ou ao tempo de canto. Método: 59 cantores eruditos profissionais, coralistas, preencheram um questionário com perguntas gerais de identificação, classificação vocal, idade, tempo de estudo e dedicação ao canto lírico. Os coralistas foram categorizados em dois grupos de acordo com a presença ou não de queixa vocal. Todos preencheram o protocolo de índice de desvantagem vocal pra o canto clássico (IDCC), que analisa o impacto da alteração vocal na voz cantada em três subescalas: incapacidade, desvantagem e defeito. Resultados: as subescalas defeito $(6,39)$ e incapacidade $(5,39)$ apresentaram maiores escores que a subescala desvantagem $(3,34)$, para todos os cantores. Além disso, foi observada relação estatisticamente significante entre a presença de queixa vocal e maior escore do IDCC ( $p<0,001$ para todas as subescalas). No grupo com queixa, mulheres apresentaram na subescala incapacidade maior escore que os homens; no grupo sem queixa, indivíduos com mais idade e mais tempo de canto apresentaram menores escores de IDCC. Conclusão: cantores líricos com queixa e/ou sintomas vocais apresentam maior índice de desvantagem no canto, com maior expressão nas subescalas de defeito e incapacidade, sem relação com a classificação vocal.

Palavras-Chave: Voz; Qualidade da Voz; Qualidade de Vida; Música.

Referenciar este material como: 


\section{Introduction}

Classical music is divided into two categories: sacred and profane. The classical opera singing is a type of profane music and corresponds to the opera itself, which requires long training, dominance of vocal projection and vocal quality rich in harmonics. Such adjustments are of complex development and, if not well executed, may favor the development of vocal alterations and cause handicaps to the singer, with quality of life consequences1.

Self-assessment protocols help to determine the impact of a voice problem in the life of an individual. The most popular self-assessment protocol for this matter is the voice handicap index (VHI), validated for the Brazilian Portuguese as Índice de desvantagem vocal (IDV)2. However, this instrument is not sensitive to the evaluation of singers. In order to suppress this need, some specific questionnaires were developed, such as the IDV for modern singing (IDCM) and IDV for classical singing (IDCC)3, in addition to the IDV for singing (IDV-C) 4, which is also available in a reduced version with only ten items5.

The aim of this study is to determine which handicaps are produced by a vocal problem and whether there are any relations to gender, age, vocal classification or total singing duration, through the application of the Brazilian version of IDCC in classical singers with and without vocal complaints.

\section{Method}

This study was approved by the ethics committee of the institution (CEP - 1515/07 CEV) and all participants signed an informed consent form. Fifty-nine individuals participated in the study. All participants were professional classical opera singers from the city of São Paulo, being 26 men and 33 women (mean age 32.82 years - being 20 the minimum and 75 the maximum age in years). The participants were divided into six groups according to the vocal classification: 22 sopranos, 10 mezzo-sopranos, one contralto, 13 tenors, 10 baritones and three bass. The population was also distributed into two groups according to presence or absence of vocal complaints: 17 choristers (27.86\%) had at least one vocal complaint and/or three or more vocal symptoms, while 42 choristers (72.18\%) had no complaints or had less than two vocal symptoms.

One questionnaire for sample identification and characterization and the IDCC protocol adapted to
Brazilian Portuguese were applied (Appendix). Participants were instructed to fill out the questionnaire and the protocol according to the instructions provided and to concentrate on their singing voice. The identification and characterization questionnaire contained data on vocal classification (according to the groups mentioned above), age, education, total dedication time to opera singing, voice quality, voice problems and presence of vocal symptoms (burning, itching, pain, dryness feeling, burning sensation, tightness or ball sensation, vocal fatigue and hoarseness). When the participant reported three or more symptoms, he or she was considered as presenting vocal complaints and, therefore, was assigned to the group with complaints. Age, educational level, and dedication time to singing were investigated by means of open questions. The remaining questions were answered on a two point scale (yes or no) to assess the presence or absence of that specific item - except for items related to vocal problem, which were answered on a three-point scale (yes, no, or sometimes); and items related to voice quality, which were answered on a five-point scale (excellent, good, fair, poor and do not know).

The IDCC - adapted version of protocol developed by the Phoniatrist Franco Fussi3 comprises 30 items, divided into three subscales: Disability, Handicap and Impairment. This division stems from the criteria used by the World Health Organization6 and refers to the classification of the impact of a disease according to the concepts of impairment: abnormality in physical or mental function, incapacity; restriction or lack of skill demonstrated in daily tasks performance handicap; social, economic and environmental difficulties resulting from a impairment or disability.

In the case of IDCC, Disability corresponds to the functional domain and refers to the impact of voice disorders in professional activities; Handicap corresponds to the emotional domain and relates to the psychological impact of voice problems; and Impairment corresponds to the organic domain, associated with self-perception of characteristics of vocal emission. In the original protocol3, each subscale consists of ten items which are answered through a Likert scale of 4 points. The adapted scale consists of 5 points, where 0 corresponds to never, 1 corresponds to almost never, 2 to sometimes, 3 almost always, and 4 always. The scores for each subscale for each individual are found through simple summation of raw scores, which could total 40 points, within each domain. The responses of the severity of each subscale were summed to 
obtain the total score for each individual with a maximum total of 120 points, being that the higher the score, the greater the severity of voice handicap.

For this study, the significance level of the results was set at 0.05 (5\%). All confidence intervals were calculated with a 95\% statistical confidence. The statistical tests and techniques used were nonparametric because the conditions for the use of parametric techniques and tests, such as normality and homoscedasticity, were not fulfilled in the current data set. The Mann-Whitney was used to compare the groups in the IDCC subscales according to gender. The differences between the subscales were determined by Wilcoxon test. The results between the groups according to vocal classification were compared by Kruskal-Wallis test. The Spearman correlation measured the degree of relationship between the scales of IDCC with the other quantitative variables.

\section{Results}

The sample was composed of 59 classical opera singers, whose average total IDCC score was 15.12 points (Table 1 ). This value represents $12.6 \%$ of a total of 120 points.

The sample was divided into two groups according to the presence of vocal complaints or symptoms. Data analysis showed that 17 choristers (27.86\%) presented vocal complaints and/or three or more vocal symptoms, whereas 42 choristers (72.18\%) had no complaints or less than two vocal symptoms (Table 1 ).
All choristers reported a good quality in their singing voice. Only $36.36 \%$ of participants from the group without vocal complaints reported symptoms, being the most mentioned: fatigue (22.72\%) and itch (6.81\%). All participants from the group with vocal complaints reported symptoms: tiredness (76.47\%), dryness (41.17\%), and pain (35.29\%).

Table 1 shows data referring to the IDCC scores according to gender and group (with and without vocal complaints). The results of IDCC scores according to vocal classification are presented in Table 2. The correlation between IDCC scores and the studied variables is presented in Table 3.

In Table 1, a statistically significant difference in all subscales between groups with and without vocal complaints, considering both genders, is observed (where $\mathrm{p}<0.001$ ). To accurately determine the differences between the subscales, they were pairwisely compared using the Wilcoxon test, which shows that the subscale Handicap is the only one that differs from the other subscales in both groups.

Regarding the comparison between genders, statistically significant difference was observed only for the subscale of Disability of the group with vocal complaints $(p=0.044)$ - women presented a higher score than men. No statistical differences were found among vocal classifications for all IDCC scales, such for the group with as for the group without vocal complaints (Table 2).

It is observed in Table 3 that negative correlations with age $(\mathrm{p}=0.012$ - Handicap, $\mathrm{p}=$ 0.004 - Impairment, and $\mathrm{p}=0.002$ - Total) and total singing duration ( $\mathrm{p}=0,025$ - Total) were found only for the group without vocal complaints.

TABLE 1. IDCC scores according to gender and group (with and without vocal complaints).

\begin{tabular}{|c|c|c|c|c|c|c|c|c|c|c|c|c|c|}
\hline & & \multicolumn{3}{|c|}{ Disability } & \multicolumn{3}{|c|}{ Handicap } & \multicolumn{3}{|c|}{ Impairment } & \multicolumn{3}{|c|}{ TOTAL } \\
\hline & & Fem & Male & Both & Fem & Male & Both & Fem & Male & Both & Fem & Male & Both \\
\hline \multirow[t]{3}{*}{ Mean } & $\begin{array}{c}\text { Without } \\
\text { complaint }\end{array}$ & 2,65 & 3,05 & 2,83 & 1,7 & 1,53 & 1,62 & 3,65 & 4,74 & 4,14 & 8 & 9,32 & 8,6 \\
\hline & $\begin{array}{c}\text { With } \\
\text { complaint }\end{array}$ & 14,2 & 8,14 & 11,71 & 9,3 & 5,14 & 7,59 & 13,6 & 9,57 & 11,94 & 37,1 & 22,86 & 31,24 \\
\hline & total & 6,15 & 4,42 & 5,39 & 4 & 2,5 & 3,34 & 6,67 & 6,04 & 6,39 & 16,82 & 12,96 & 15,12 \\
\hline \multirow[t]{3}{*}{$\begin{array}{l}\text { Standard } \\
\text { deviation }\end{array}$} & $\begin{array}{c}\text { Without } \\
\text { complaint }\end{array}$ & 2,25 & 3,21 & 2,7 & 2,7 & 2,34 & 2,52 & 3,96 & 3,93 & 3,94 & 7,07 & 6,9 & 6,94 \\
\hline & $\begin{array}{c}\text { With } \\
\text { complaint }\end{array}$ & 6,46 & 4,74 & 6,43 & 6,65 & 5,21 & 6,29 & 6,45 & 5,22 & 6,15 & 17,69 & 14,33 & 17,47 \\
\hline & total & 6,65 & 4,25 & 5,74 & 5,48 & 3,62 & 4,78 & 6,64 & 4,74 & 5,84 & 17,52 & 11,01 & 15,01 \\
\hline \multirow[t]{3}{*}{ p-value } & Without & \multicolumn{2}{|c|}{0,949} & \multirow[b]{2}{*}{$<0,001^{*}$} & \multicolumn{2}{|c|}{0,588} & & \multicolumn{2}{|c|}{0,324} & \multicolumn{4}{|c|}{0,455} \\
\hline & $\begin{array}{l}\text { complaint } \\
\text { With } \\
\text { complaint }\end{array}$ & \multicolumn{2}{|c|}{$0,044^{*}$} & & \multicolumn{2}{|c|}{0,115} & $<0,001^{*}$ & \multicolumn{2}{|c|}{0,222} & $<0,001^{*}$ & \multicolumn{2}{|c|}{ 0,050\# } & $<0,001^{*}$ \\
\hline & total & \multicolumn{2}{|c|}{0,438} &.. & \multicolumn{2}{|c|}{0,225} & .. & \multicolumn{2}{|c|}{0,969} &.. & \multicolumn{2}{|c|}{0,663} & .. \\
\hline
\end{tabular}

Wilcoxon test: Group with vocal complaint: Handicap X Disability p<0,001; Impairment X Disability p=0,391, Impairment X Handicap p <0,001. Group without vocal complaint: Handicap X Disability; $\mathbf{p}<0,001$, Impairment X Disability p=0,590, Impairment X Handicap p<0,001. 
TABLE 2. IDCC scores according to vocal classification and group (with and without vocal complaints).

\begin{tabular}{|c|c|c|c|c|c|}
\hline & & & Mean & Standard Deviation & p-Value \\
\hline \multirow[t]{9}{*}{ disability } & \multirow{5}{*}{ Without complaint } & Bass & 1 & 1 & \multirow{5}{*}{0,552} \\
\hline & & Baritone & 3 & 3,35 & \\
\hline & & Mezzo & 2,63 & 0,92 & \\
\hline & & Soprano & 2,67 & 2,74 & \\
\hline & & Tenor & 3,7 & 3,5 & \\
\hline & \multirow{4}{*}{ With complaint } & Baritone & 5,25 & 3,2 & \multirow{4}{*}{$0,064 \#$} \\
\hline & & Mezzo & 12,5 & 3,54 & \\
\hline & & Soprano & 15,29 & 7,43 & \\
\hline & & Tenor & 12 & 3,61 & \\
\hline \multirow[t]{9}{*}{ Handicap } & \multirow{5}{*}{ Without complaint } & Bass & 1,67 & 2,89 & \multirow{5}{*}{0,649} \\
\hline & & Baritone & 1,17 & 1,83 & \\
\hline & & Mezzo & 2,88 & 4,19 & \\
\hline & & Soprano & 1,07 & 1,22 & \\
\hline & & Tenor & 1,7 & 2,67 & \\
\hline & \multirow{4}{*}{ With complaint } & Baritone & 2,25 & 2,06 & \multirow{4}{*}{ 0,098\# } \\
\hline & & Mezzo & 6 & 1,41 & \\
\hline & & Soprano & 10 & 7,83 & \\
\hline & & Tenor & 9 & 6 & \\
\hline \multirow[t]{9}{*}{ impairment } & \multirow{5}{*}{ Without complaint } & Bass & 3,67 & 5,51 & \multirow{5}{*}{0,503} \\
\hline & & Baritone & 5 & 2,83 & \\
\hline & & Mezzo & 5,13 & 4,16 & \\
\hline & & Soprano & 2,87 & 3,76 & \\
\hline & & Tenor & 4,9 & 4,38 & \\
\hline & \multirow{4}{*}{ With complaint } & Baritone & 7,5 & 4,43 & \multirow{4}{*}{0,252} \\
\hline & & Mezzo & 16 & 1,41 & \\
\hline & & Soprano & 13,71 & 7,41 & \\
\hline & & Tenor & 12,33 & 5,69 & \\
\hline \multirow[t]{8}{*}{ TOTAL } & \multirow{4}{*}{ Without complaint } & Bass & 6,33 & 9,29 & \multirow{4}{*}{0,415} \\
\hline & & Baritone & 9,17 & 5,91 & \\
\hline & & Mezzo & 10,63 & 7,54 & \\
\hline & & $\begin{array}{c}\text { Soprano } \\
\text { Tenor }\end{array}$ & 6,6 & $\begin{array}{l}6,64 \\
7,26\end{array}$ & \\
\hline & \multirow{4}{*}{ With complaint } & Baritone & 15 & 8,29 & \multirow{4}{*}{$0,072 \ddagger$} \\
\hline & & Mezzo & 34,5 & 0,71 & \\
\hline & & Soprano & 39 & 21,25 & \\
\hline & & Tenor & 33,33 & 15,01 & \\
\hline
\end{tabular}

TABLE 3. Correlations between IDCC and qualitative variables for the groups with and without vocal complaints.

\begin{tabular}{|c|c|c|c|c|c|c|}
\hline & & & Disability & Handicap & Impairment & TOTAL \\
\hline Age & $\begin{array}{l}\text { without complaint } \\
\text { with complaint }\end{array}$ & $\begin{array}{c}\text { Corr } \\
\text { p-value } \\
\text { Corr } \\
\text { p-value }\end{array}$ & $\begin{array}{c}-28,40 \% \\
0,109 \\
14,00 \% \\
0,618 \\
\end{array}$ & $\begin{array}{c}-43,40 \% \\
0,012 * \\
-17,40 \% \\
0,535 \\
\end{array}$ & $\begin{array}{c}-48,80 \% \\
0,004 * \\
3,50 \% \\
0,901 \\
\end{array}$ & $\begin{array}{c}-51,30 \% \\
0,002 * \\
1,90 \% \\
0,947 \\
\end{array}$ \\
\hline Total singing duration & $\begin{array}{l}\text { without complaint } \\
\text { with complaint }\end{array}$ & $\begin{array}{c}\text { Corr } \\
\text { p-value } \\
\text { Corr } \\
\text { p-value }\end{array}$ & $\begin{array}{c}-26,20 \% \\
0,093 \# \\
17,50 \% \\
0,518 \\
\end{array}$ & $\begin{array}{c}-25,00 \% \\
0,11 \\
23,30 \% \\
0,385 \\
\end{array}$ & $\begin{array}{c}-28,10 \% \\
0,072 \# \\
25,90 \% \\
0,333 \\
\end{array}$ & $\begin{array}{c}-34,50 \% \\
0,025^{*} \\
28,70 \% \\
0,281 \\
\end{array}$ \\
\hline Singing Class & $\begin{array}{l}\text { without complaint } \\
\text { with complaint }\end{array}$ & $\begin{array}{c}\text { Corr } \\
\text { p-value } \\
\text { Corr } \\
\text { p-value }\end{array}$ & $\begin{array}{c}9,80 \% \\
0,562 \\
41,90 \% \\
0,12 \\
\end{array}$ & $\begin{array}{c}6,40 \% \\
0,707 \\
39,10 \% \\
0,15 \\
\end{array}$ & $\begin{array}{c}11,20 \% \\
0,508 \\
32,90 \% \\
0,231 \\
\end{array}$ & $\begin{array}{c}6,60 \% \\
0,696 \\
48,20 \% \\
0,069 \# \\
\end{array}$ \\
\hline Hours of rehearsal & $\begin{array}{l}\text { without complaint } \\
\text { with complaint }\end{array}$ & $\begin{array}{c}\text { Corr } \\
\text { p-value } \\
\text { Corr } \\
\text { p-value }\end{array}$ & $\begin{array}{c}-3,30 \% \\
0,842 \\
10,20 \% \\
0,707 \\
\end{array}$ & $\begin{array}{c}-4,80 \% \\
0,77 \\
-3,50 \% \\
0,897 \\
\end{array}$ & $\begin{array}{c}5,10 \% \\
0,754 \\
27,50 \% \\
0,303 \\
\end{array}$ & $\begin{array}{c}2,20 \% \\
0,894 \\
14,50 \% \\
0,592 \\
\end{array}$ \\
\hline Weekly singing & $\begin{array}{l}\text { without complaint } \\
\text { with complaint }\end{array}$ & $\begin{array}{c}\text { Corr } \\
\text { p-value } \\
\text { Corr } \\
\text { p-value }\end{array}$ & $\begin{array}{c}-14,60 \% \\
0,355 \\
25,00 \% \\
0,333\end{array}$ & $\begin{array}{c}-9,10 \% \\
0,568 \\
-0,70 \% \\
0,977\end{array}$ & $\begin{array}{c}-1,60 \% \\
0,919 \\
24,80 \% \\
0,338\end{array}$ & $\begin{array}{c}-7,30 \% \\
0,648 \\
22,10 \% \\
0,394\end{array}$ \\
\hline
\end{tabular}




\section{Discussion}

The literature addressing the impact of vocal alterations in singers - especially classical opera singers - is still scarce. It was observed that opera singers reported good voice as well as low voice handicap related to singing (12.6\%). This is probably due to the demands of opera singing and the training required by this type of singing, which features a nonsignificant impact on their quality of life. However, it is verified that singers with vocal complaints have more symptoms and perceive more handicap related to singing $(\mathrm{p}<0.001)$ due to their voice problem (Table 1). Such handicap, although not signifying a vocal alteration itself, can point an unsatisfactory vocal performance in singing activity.

In the current study, the results suggest that the biggest impairment perceived by opera singers is at the subscales of Impairment and Disability, as have their scores were significantly higher than the subscale Handicap (Table 1). This suggests that opera singers may realize, for example, vocal performance variance along the day, and more vocal tiredness during or after the presentations (according to most listed items in the protocol); but nothing to cause significant concern or anxiety about their singing performance. Even in non-singers, less severe vocal alterations may have smaller impact on emotional aspects when compared to organic and functional aspects of their quality of life related to voice 7 .

It is interesting to highlight that (Table 1) the group of choristers with vocal complaints $(n=17)$ is much smaller as compared to the group without vocal complaints $(n=42)$. It is believed that the requirements of classical singing do not allow such professionals to have many complaints or voice disorders, differently from popular singing. Differences between professional and amateur singers, popular and classical singers can be observed both in speech 1,8 as in singing voice. Moreti et al.9 investigated the

\section{Conclusions}

The results of this study that investigated the voice handicap in classical singers, with and without vocal complaints, indicate that:

. classical singers reported good voice and low vocal handicap related to singing which, when present, is manifested at organic and functional domains; voice handicap of amateur choristers of popular singing using the IDCM - protocol similar to the IDCC. The authors reported diverse results. Their findings show that in the absence of vocal complaints, amateur singers have reported a greater handicap when compared to classical singers probably due to the possible lower demand for a stable condition and the absence of specific training.

Considering the analysis according to gender, we observed that in the group with complaints, women showed significantly higher scores than men (Table 1) in the subscale of Disability. This may indicate that women perceive a greater impact on issues of professional nature. However, from the standpoint of vocal classification, shown in Table 2, there are no significant differences between groups which confirm the similarity in vocal requirement for all vocal classifications10. As for other variables such as age and total singing duration, for the group without complaint, age was negatively correlated with the Impairment, Handicap subscales and with the total IDCC score. This indicates that the higher the age, the smaller the perceived handicap. Likewise, longer total singing duration correlates with lower total IDCC score (Table 3). Probably, the increased age and singing duration enable better learning about vocal technique and voice care. However, some studies using a protocol developed for evaluation of singing voice - the Singing Voice Handicap Index (SVHI) have shown increase in the SVHI score at ages above 50 years, perhaps due to the vocal aging process 11 .

Despite the fact that difficulties mentioned by the choristers from the present study not necessarily indicate the presence of dysphonia, the IDCC was sensitive to the population of singers with complaints: the increased report of vocal complaints represents the highest IDCC score. Furthermore, the protocol is an important tool for professionals who work with singers and can be useful to define the needs of this group.

. there is a highest index of handicap in the presence of vocal complaints, being that women perceive a greater impact in the functional domain;

. in the absence of vocal complaints, younger and with less total singing duration individuals perceive highest vocal handicap index. 


\section{APPENDix}

CSHI (Classic Singing Handicap Index) - IDCC (Índice de Desvantagem para o Canto Clássico)

Marque a resposta que indica o quanto você compartilha da mesma experiência:

Chave de resposta: 0 - nunca; 1 - quase nunca; 2 - às vezes; 3 - quase sempre; 4 - sempre

O impacto do problema de voz nas atividades profissionais (Disability - Incapacidade).

\begin{tabular}{|c|c|c|c|c|c|c|}
\hline 1 & Tenho dificuldades durante as apresentações por causa de alterações de meu rendimento vocal. & 0 & 1 & 2 & 3 & 4 \\
\hline 2 & Tenho levado mais tempo para aquecer a minha voz. & 0 & 1 & 2 & 3 & 4 \\
\hline 3 & Minha voz fica cansada ou alterada durante as apresentações. & 0 & 1 & 2 & 3 & 4 \\
\hline 4 & Tenho que mudar aspectos da minha técnica vocal, porque o problema de voz prejudica a minha emissão. & 0 & 1 & 2 & 3 & 4 \\
\hline 5 & Meu problema vocal me obriga a modificar músicas ou limitar meu repertório. & 0 & 1 & 2 & 3 & 4 \\
\hline 6 & Por causa do meu problema de voz sou forçado a limitar meu tempo habitual de estudo/ensaio. & 0 & 1 & 2 & 3 & 4 \\
\hline 7 & Sou obrigado a fazer períodos de descanso vocal mais longos entre as apresentações ou produções. & 0 & 1 & 2 & 3 & 4 \\
\hline 8 & Preciso evitar dinâmicas de volume em “pianíssimo”. & 0 & 1 & 2 & 3 & 4 \\
\hline 9 & Preciso tomar remédios continuamente para mascarar meu problema de voz. & 0 & 1 & 2 & 3 & 4 \\
\hline 10 & Meu problema vocal me obriga a limitar o uso social da voz. & 0 & 1 & 2 & 3 & 4 \\
\hline
\end{tabular}

O impacto psicológico do problema de voz (Handicap - Desvantagem)

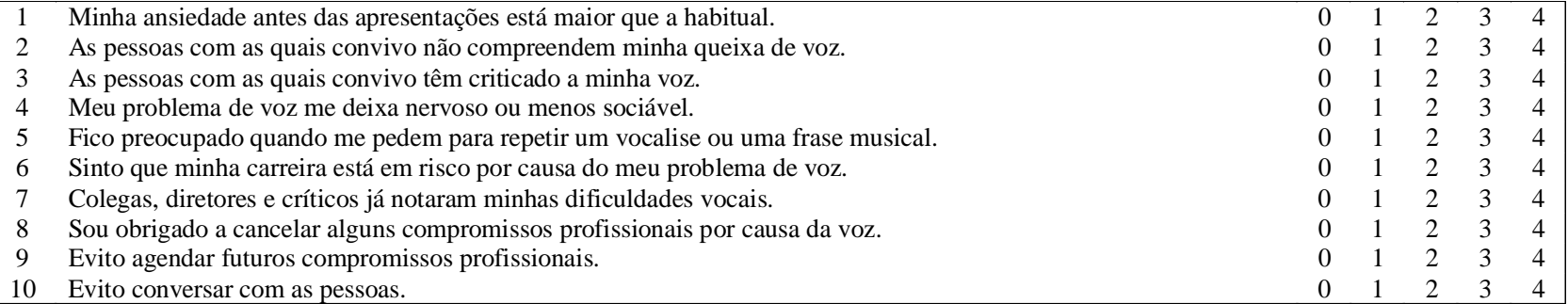

Auto-percepção das características de minha voz (Impairment - Defeito)

\begin{tabular}{|c|c|c|c|c|c|c|}
\hline 1 & Tenho dificuldades com o controle respiratório por causa do meu problema de voz. & 0 & 1 & 2 & 3 & 4 \\
\hline 2 & Meu rendimento vocal varia durante o dia. & 0 & 1 & 2 & 3 & 4 \\
\hline 3 & Acho que minha voz cantada está rouca ou ruidosa. & 0 & 1 & 2 & 3 & 4 \\
\hline 4 & Tenho dificuldades em sustentar as notas (quebra de nota). & 0 & 1 & 2 & 3 & 4 \\
\hline 5 & Minha extensão vocal reduziu ou mudou. & 0 & 1 & 2 & 3 & 4 \\
\hline 6 & Tenho dificuldades para equilibrar a ressonância ou os registros vocais. & 0 & 1 & 2 & 3 & 4 \\
\hline 7 & Cantar tem sido difícil ou cansativo e tenho que forçar a voz para produzir os sons. & 0 & 1 & 2 & 3 & 4 \\
\hline 8 & Minha qualidade vocal piora durante as apresentações. & 0 & 1 & 2 & 3 & 4 \\
\hline 9 & Após as apresentações, minha voz fica cansada ou alterada. & 0 & 1 & 2 & 3 & 4 \\
\hline 10 & Meu rendimento vocal piora em alguns momentos do dia. & 0 & 1 & 2 & 3 & 4 \\
\hline
\end{tabular}

\section{Reference}

1. Santos LMA, Gasparini G, Behlau M. Validação do protocolo do Índice de Desvantagem Vocal (IDV) no Brasil [monografia]. São Paulo: Centro de Estudos da Voz; 2007.

2. Rosen CA, Murry T. Voice Handicap Index in Singers. J Voice. 2000;14(3):370-7.

3. Fussi F. La valutazione del canto. In: Fussi F. La voce del cantante. Torino: Omega Edizioni; 2005.v.3. p. 33-68.

4. Cohen SM, Jacobson BH, Garrett CG, Noordzij JP, Stewart MG, Attia A et al. Creation and validation of the Singing Voice Handicap Index. Ann Oto Rhino Laryngol. 2007; 116(6):402-6.

5. Cohen SM, Statham M, Rosen CA, Zullo T. Development and validation of the Singing Voice Handicap-10. Laryngoscope. 2009;119(9):1864-9.

6. World Health Organization. International classification of impairments, disabilities and handicaps: a manual of classification relating to the consequences of disease. Genebra: World Health Organization, 1980.
7. Jacobson B, Johnson A, Grywalsky C. The Voice Handicap Index (VHI): development and validation. Am J Speech Language Pathol. 1997;6:66-70.

8. Murry T, Zschommler A, Prokop J. Voice Handicap in singers. J Voice. 2009;23(3):376-9.

9. Moreti F, Rocha C, Borrego MCM, Behlau M. Desvantagem vocal no canto: análise do protocolo Índice de Desvantagem para o Canto Moderno - IDCM. Rev Soc Bras Fonoaudiol. No prelo 2009.

10. Jotz GP, Bramati O, Schimidt VB, Dornelles S, Gigante LP. Aplicação do "Voice Handicap Index" em Coralistas. Arq Otorrinolaringol. 2002; 6(4):260-64.

11. Cohen SM, Noordzij JP, Garrett CG, Ossoff RH. Factors associated with perception of singing voice handicap. Otolaryngol Head Neck Surg. 2008;138(4):430-4. 